\title{
Technical Considerations in the Freezing, Low-Temperature Storage and Thawing of Stem Cells for Cellular Therapies
}

\author{
Charles J. Hunt \\ Sawston, UK
}

\section{Keywords}

Cryopreservation · Cryoprotectants · Freezing ·

Low-temperature storage · Thawing · Stem cells · Cell therapy

\begin{abstract}
The commercial and clinical development of cellular therapy products will invariably require cryopreservation and frozen storage of cellular starting materials, intermediates and/or final product. Optimising cryopreservation is as important as optimisation of the cell culture process in obtaining maximum yield and a consistent end-product. Suboptimal cryopreservation can lead not only to batch-to-batch variation, lowered cellular functionality and reduced cell yield, but also to the potential selection of subpopulations with genetic or epigenetic characteristics divergent from the original cell line. Regulatory requirements also impact on cryopreservation as these will require a robust and reproducible approach to the freezing, storage and thawing of the product. This requires attention to all aspects of the application of low temperatures: from the choice of freezing container and cryoprotectant, the cooling rate employed and its mode of delivery, the correct handling of the frozen material during storage and transportation, to the eventual thawing of the product by the end-user. Each of these influences all of the others to a greater or lesser extent and none should be ignored. This paper seeks to provide practical insights and alternative solutions to the technical challenges faced during cryopreservation of cells for use in cellular therapies.
\end{abstract}

C 2019 S. Karger AG, Basel
() 2019 S. Karger AG, Basel

\section{Introduction}

Regenerative medicine has been defined as the replacement or regeneration of human cells, tissue or organs to restore or establish normal function [1]. It encompasses a wide range of therapeutic modalities from organ and tissue transplantation to sophisticated tissue-engineered scaffolds and cellular therapies, as well as more traditional treatments involving pharmaceuticals, biologics, and devices [2]. It includes hospital-produced biologics such as autologous bone marrow and peripheral blood stem cells (PBSCs), as well as allogeneic tissue products such as cord blood (CB), heart valves and split-thickness skin produced by public/private tissue banks. More recently, the field has expanded to include a range of new cellular therapies based on adult, embryonic (hESC) and induced pluripotent stem cells (iPSC), as well as somatic cells, with the emphasis beginning to shift towards involvement of commercial biopharma, often in collaboration with academic and clinical partners.

In contrast to traditional haematopoietic stem cell therapies, the newly emerging cellular therapies are a divergent class of products which in addition to being classified by cell type, can also be classified by therapeutic indication, administration status (autologous or allogeneic), level of manipulation involved in their production as well as by their underlying technology [3]. From a regulatory perspective, within the European Union (EU), these newly emerging cell therapies are referred to as advanced therapy medicinal products [4] which are further 
subdivided on a technological basis into somatic cell, gene therapy and tissue-engineered products. In the USA, cellular therapy products include immunotherapies, cancer vaccines and other types of autologous and allogeneic cell therapies including those utilising haematopoietic, adult and embryonic stem cells [5].

To date, few cellular therapy products have emerged on the market. At the end of 2015, there were 38 licensed cellular therapy products in Canada, the EU, Japan, Korea, and the USA [6]. More recent figures for the EU indicate that market authorisations have been given for a total of 10 advanced therapy medicinal products [7] with the USA having approved 16 cellular and gene therapy products as of December 2018 [8]. Notwithstanding, there are currently numerous clinical trials in various stages of progress: the clinical trials database listing 93 studies for mesenchymal stem cells (MSCs) and 40 involving hESCs and iPSCs for a wide variety of therapeutic applications $[9,10]$, while the potential of the cellular therapy field has led to it being recognised as the fourth therapeutic pillar of global healthcare [11].

The application of any therapy to humans requires that it be manufactured and distributed within a regulatory framework to ensure safety and efficacy. This framework not only includes the manufacturing process but also upstream events such as procurement of starting materials and the downstream storage and distribution of the product. In the case of cellular therapies, the need to store cellular material, or conserve particular cellular attributes, at sometimes multiple points in the manufacturing process necessitates the introduction of a cryopreservation step. In a recent study by the Food and Drug Administration (FDA), over $80 \%$ of MSC submissions were found to use cryopreservation as part of the manufacturing process to store and deliver their product [12].

Cryopreservation provides a substantial number of benefits: it obviates the need to maintain cells in longterm culture, with its attendant problems of epigenetic change and genetic drift; it allows desired cell phenotypes to be maintained through the storage of master and working cell banks; it permits quarantining of donor cells and final product to allow extended microbiological testing while, from a commercial perspective, it provides the product with a shelf life and simplifies logistical problems associated with transporting cells within or between facilities. Therapeutically, it permits multiple treatments from the same batch of cells and flexibility in timing of treatment for the patient.

During manufacture, the cryopreservation process both sometimes precedes, and usually follows, cell culture and expansion and is an integral part of the banking process. The final product itself, if frozen, will need to be stored, transported at an appropriate sub-zero temperature and eventually thawed before administering to the patient. As such, the efficacy and stability of the final product is as dependent on these processes as it is on the rest of the manufacturing process. Nevertheless, though a key component, cryopreservation often takes a back seat to other areas of bioprocessing when it comes to optimisation and control. This lack of attention to a key manufacturing process has been identified as a potential bottleneck in the future development of complex cellular therapy products $[13,14]$. A thorough understanding of the cryopreservation process, including low temperature storage, is therefore vital for successful commercial manufacture of cellular therapies.

However, the diversity of cellular therapies and the wide variety of cellular starting materials makes it unlikely that a universal cryopreservation process is achievable. This makes it all the more important that fundamental cryobiological principles are understood and applied correctly. Comprehensive reviews of the principles of cryobiology and the biological response of cells to the application of sub-zero temperatures are beyond the scope of this paper and can be found elsewhere [15-17]. The purpose of this paper is to identify technical challenges common to all cryopreservation processes regardless of the cell or tissue type used and the format in which the cellular therapy is delivered.

\section{Cryopreservation}

Cryopreservation is the application of low temperatures to preserve the structural and functional integrity of cells and tissues during which the aqueous phase typically undergoes a phase change to form ice. Once frozen, cells and tissue can be stored in a stable state provided that the sub-zero temperature attained is low enough: typically, at or near the temperature of liquid nitrogen $\left(-196^{\circ} \mathrm{C}\right)$. Alternatively, preservation may be achieved by vitrification which is the solidification of an aqueous system without crystallisation and the growth of ice [18]. During cryopreservation, significant cell survival and maintenance of structural integrity can only be achieved by using compounds collectively known as cryoprotective agents (CPAs). In low concentration, CPAs mitigate the damage caused by slow cooling, where extracellular ice formation during freezing causes a substantial increase in the concentration of damaging solutes. Used in high concentration, or in combination, they help promote vitrification at low, realistically achievable, cooling rates.

Unfortunately, not all cells and tissues respond equally to a given cryopreservation protocol. Differences in their physical and biological make-up, such as membrane permeability and surface to volume ratio, produce varying responses to the cryopreservation process leading to dif- 
ferences in viability on subsequent thawing. Furthermore, the metabolic and functional "health" of the cells entering the cryopreservation process will affect the outcome and the concept of "garbage in, garbage out" is as applicable to cryopreservation as it is to computer science.

It is necessary, therefore, not only to optimise the cell culture process but to optimise the cryopreservation protocol for the cell type(s) of interest rather than to adopt an off-the-shelf protocol which, whilst offering some post-thaw recovery, may nevertheless lead to a significant loss of viability and functionality. This loss can be as high as $60-70 \%$ with some reported stem cell cryopreservation protocols, depending on the assay used and the time of its application post-thaw [19]. Though suboptimal preservation may seem acceptable, given the ability of the cells to expand post-thaw, it may impose an undesirable selection pressure which is expressed during subsequent culture. Moreover, suboptimal cryopreservation has been shown to lead to chromosomal damage and epigenetic changes [20], whilst the presence of apoptotic and necrotic cells in the final product prior to application to the patient may invoke an inflammatory response or induce an abnormal immunological reaction [21]. Whilst an empirical approach to optimising the cryopreservation protocol has generally been applied, in the context of a regulated cellular therapy this approach may not be desirable and a methodological or quality by design approach may be more appropriate $[22,23]$.

Cryopreservation can be subdivided into a number of interrelated elements all of which need to be controlled and each of which poses its own technical challenges:

- Choice of container system

- Choice of the CPA and vehicle solution

- Protocol for adding the CPA

- Choice of a freezing or vitrification process

- Mode of cooling

- Storage conditions

- Thawing and elution of CPA

- Viability assessment

All these need to be considered, both individually and collectively, for potential effects on the quality of the final product, as early in the product development cycle as possible. Moreover, within a regulatory environment, which will encompass the need for a robust quality management system, whatever choices are made will have to be risk assessed and the equipment, materials, and processes validated to demonstrate fitness for purpose.

\section{Choice of Container System}

There are a number of options for the frozen storage of cell therapy products, the choice of which will be dictated by a number of factors including the intended use of the cells, the cell density, and the volume required. In addition to sterility assurance, for products intended for human therapy, there will be additional regulatory requirements including absence of bioactive leachables and other particulates as well as closure integrity during storage [24].

\section{Cryovials}

While the use of standard cryovials is routine practice, especially for research and development, these are unlikely to be appropriate for clinical or scaled-up processes and are not considered best practice as they represent a potential contamination hazard to stored cells [25]. Some cryovials are CE marked as IVDs (e.g., Nunc ${ }^{\mathrm{TM}}$ ). However, not all cryovials are provided sterile. If using cryovials, those with a sterility assurance level of $10^{-6}$ according to ISO 1137 and/or gamma-irradiated should be used where sterility of the product is a consideration. While gasketed, internal-threaded vials are preferable to those with an external thread from the point of view of contamination during filling, neither offers a closed-system fill nor a hermetic seal during low-temperature storage: of significance if samples are stored under liquid nitrogen $\left(\mathrm{LN}_{2}\right)$. The use of heat shrink sleeving as an overwrap, especially if combined with gas phase $\mathrm{LN}_{2}$ storage, may provide an additional level of protection though a hermetic seal is not guaranteed by the manufacturer and there are concerns that the heating process could damage the cells. An alternative method of application of the sleeving has been suggested, which was demonstrated to have no adverse effect on cell survival during application and prevented ingress of $\mathrm{LN}_{2}$ during storage in the liquid phase [26].

Traceability and sample tracking are of considerable importance within a regulatory framework and this applies to frozen-stored intermediates as well as the final product. Linear and 2-D bar-coded cryovials are available from a range of suppliers in bulk or in a variety of formats including SBS 48-vial format (e.g., Fluidx, www.brookslifesciences.com). More recently RFID tags compatible with $\mathrm{LN}_{2}$ storage temperatures and capable of being retro-fitted to standard cryovials have been introduced (Cryogatt, www.cryogatt.com). Ultra-cold-resistant chips are being developed which, when fitted within individual cryovials, could store not only a detailed thermal history but also detailed batch information, test results, and other relevant quality documentation [14].

Alternatives to the standard cryovial, which are more suitable for clinical applications, exist. CellSeal ${ }^{\circledR}$ closedsystem cryogenic vials (www.cookregentec.com) provide a ported system which can be sealed using a standard RF sealer [27] and for which a semi-automated filling system has been developed. A heat-sealable cryotube has also been developed by CryoBioSystems (www.cryobiosystem.com) with the same isomeric resin used for their vit- 
rification straws. These tubes are CE-marked and classified as class II medical devices. A device for sealing the tubes is also available.

\section{Closed-System Plastic Alternatives}

Whilst automated systems for filling cryovials exist, these are more suited to smaller batch sizes in the 10-100 vial range. Container systems for large-scale production of small-dosage, therapeutic cells will require a different approach to both the container and the filling system. The use of closed-system plastic vials coupled with pharmaceutical fill technologies will allow the processing of large batches from several hundred to several thousand vials.

Daikyo Crystal Zenith ${ }^{\circledR}$ clear, plastic pharmaceutical vials made from a cyclic olefin polymer (www.westpharma.com) have been used successfully for the cryopreservation of MSC frozen and stored at $-196^{\circ} \mathrm{C}$ [28]. A unique system, developed by Aseptic Technologies (AT-Closed $\mathrm{Vial}^{\circledR}$, www.aseptictech.com), employs a thermoplastic, pre-closed, sterile, septum vial capable of being frozen to and stored at $-196^{\circ} \mathrm{C}$. Each vial is filled via a needle inserted though the thermoplastic septum which is then resealed using a laser. Both manual and automated fill systems are available making this a very versatile system [29].

A commercially available, ported, gas-permeable cassette (CLINICELL ${ }^{\circledR}$, www.mabio.net) suitable for both cell culture and subsequent freezing and storage in the gas phase of $\mathrm{LN}_{2}$ has been developed. It allows in situ freezing after substitution of the culture medium with CPA [30].

\section{Cryobags}

Freezing large quantities of cells is a necessity for therapeutic cell banking. This will require either large volumes or reduced volumes of highly concentrated cells. Additionally, bioreactor systems often require seeding with high numbers of cells from working cell banks or starter cultures. Freezing bags, generally used for the cryopreservation of bone marrow and peripheral blood stem cells, have been used successfully to store frozen mammalian cell lines [31]. Closed-bag systems, which may obviate the need for expensive clean-room facilities, have also been developed for PBSCs. Here, long-term follow-up data indicates that the products are comparable with those produced in conventional cleanroom facilities [32] and the system has been accepted by EU regulatory authorities [33]. Recently, the use of frozen "seed bags" (Cell Freeze ${ }^{\circledR}$; https://www.chartermedical.com) for the cryopreservation of the large-volume inocula required for bioreactors has been demonstrated [34].

Until recently, the fill volumes available (of the order of 50-100 mL) have restricted the use of cryobags largely to cryopreservation of bone marrow and PBSCs. Though smaller bags have been available for cryopreservation of $\mathrm{CB}$ in specialist, combined controlled-rate freezing/stor- age systems (Thermogenesis BioArchive ${ }^{\circledR}$, www.cescatherapeutics.com/), bags with small fill volumes were unavailable. However, multiple-chamber cryobags with fill volumes of up to $6 \mathrm{~mL}$ per chamber have become available (Cryostore ${ }^{\mathrm{TM}}$, www.origen.com), which should allow the use of cryobags as containers of choice in future cellular therapies. As with cryovials, overwrap bags are available to allow "double-bagging" of the primary container to reduce contamination risk and provide a sterile inner bag for direct-to-patient use.

\section{Vitrification Straws and Dishes}

Unless complex multiple CPAs are used in combinations which allow vitrification at slow cooling rates, there are limited container options available that will allow the ultra-rapid cooling rates necessary for vitrification. Generally, these are limited to open-ended vitrification straws, which pose significant contamination issues from nonsterile $\mathrm{LN}_{2}$. A straw-in-straw method for vitrification of mouse embryos and neurospheres has been successfully employed [35] and methods to cryopreserve ESCs in cryovials have been explored [36]. Recently, a novel cell culture dish (TWIST) suitable for plate-based vitrification of adherent cells has been developed [37], with implications for the cryopreservation of cells in plate formats for a wide variety of screening applications.

\section{Choice of CPA}

CPAs protect cells predominantly from the damaging effects of freezing at slow cooling rates (i.e., those generally achievable using commercially available passive cooling devices [PCDs] and controlled-rate freezers [CRFs]). When added in sufficient concentration, they depress the freezing point of the solution, reducing the amount of ice formed at any given sub-zero temperature, thereby reducing the concentration of salts in the unfrozen fraction and mitigating solute damage. Other protective effects, including membrane stabilisation, have also been demonstrated [38].

CPAs can be divided into two groups: small-molecular-weight penetrating CPAs (e.g., dimethyl sulphoxide [DMSO], glycerol, ethylene glycol, and propylene glycol) and high-molecular-weight non-penetrating agents (e.g., sucrose, polyvinylpyrrolidone, and hydroxyethyl starch).

The effectiveness of any given penetrating CPA will depend to a certain extent on the permeability of the cell type to it and any chemical toxicity that the cell may experience from it. The degree of protection afforded by the CPA will depend on a number of variables: concentration, temperature of exposure, length of exposure, the rate and concentration steps used in the addition and removal of the CPA, the carrier solution used for the CPA 
and any osmotic buffering used during its removal. All of these interact and need to be considered during optimisation of the cryopreservation process, as will the interaction of the CPA with other variables such as cooling and warming rate.

\section{Osmotic Damage and Chemical Toxicity}

Penetrating CPAs, like DMSO pass through the cell membrane more slowly than water. Exposure to a solution containing a permeating CPA will thus lead to a temporary osmotic imbalance as water moves out of the cell more rapidly than permeating CPA can move in. A similar osmotic transient will occur in reverse during the removal of the CPA as water moves into the cell faster than CPA moves out. These osmotic transients must be controlled to prevent cellular damage as cells shrink or swell beyond tolerated limits.

Though single-step addition of CPAs used at concentrations of $<2 \mathrm{M}$ is often considered safe, adding in sequentially increasing concentrations often provides improved survival [39]. On the other hand, unloading the CPA in a single step, such as centrifugation of the cells and replacement with a CPA-free solution, is likely to lead to damaging osmotic transients as the cells undergo unrestricted cell swelling in response to the osmotic imbalance. Two-step dilution of the CPA (or even multi-step elution protocols), or the use of an "osmotic buffer" such as sucrose or mannitol during unloading will help prevent damaging osmotic transients [38].

Chemical toxicity is another potentially damaging factor that must be considered; both in the choice of CPA and in the concentration used [40]. While few toxic events have been linked to non-penetrating CPA, the ability of the penetrating CPAs to enter the cell, where they can interact with cellular processes, makes this class of compound more likely to demonstrate cellular toxicity. Additionally, the time allowed for equilibration and the temperature of exposure prior to freezing, as well as contact time post-thaw, will be contribute to this toxicity. Reducing the time and lowering the temperature during loading and unloading will help keep unwanted cytotoxic effects to a minimum.

\section{Automated Filling Systems}

Once exposed to the CPA, reducing the time taken before commencing the freezing process will help reduce unwanted cytotoxic effects. With medium to large batch sizes the time taken to manually aliquot the cell suspension into vials can be significant. Moreover, maintaining a low temperature within a cleanroom environment is often difficult. The only realistic alternative is to shorten exposure times by reducing the length of the aliquoting process. This has the added benefit of reducing the potential for contamination throughout the aseptic fill process.
Small, capper-decapper fillers are available such as the XSD-Biofill (www.brookslifesciences.com) and the Fill-It (www.sartorius-stedim-tap.com) both of which provide automated filling of SBS plates in a variety of formats. Both devices will fit within a class II microbiological safety cabinet, maintaining the air quality requirements for aseptic fill operations.

\section{Dimethyl Sulphoxide}

The most widely used CPA is undoubtedly DMSO. Alone, or in combination with other permeating and non-permeating CPAs, it is the CPA of choice in most research and biobanking situations. However, regardless of its effectiveness in preserving a wide variety of cells and tissues and its long therapeutic use, notably in PBSCs and $\mathrm{CB}$ cryopreservation, concerns have been raised in relation to its use for cellular therapy.

DMSO is known to have diverse effects on the differentiation potential of hESCs [41] and can affect epigenetic status and induce apoptosis in some cells $[42,43]$. However, these effects are usually generated after exposure over many hours to days in culture at $37^{\circ} \mathrm{C}$ - conditions unlike those experienced during cryopreservation.

\section{Clinical Exposure to DMSO}

Clinically, allergic reactions, some severe and occasionally fatal, have been reported in patients infused directly with haematopoietic stem cells containing DMSO [44]. However, a recent prospective, multicentre surveillance study has suggested that factors unrelated to the CPA may be the cause of these reactions [45]. The debate surrounding the use of DMSO has led to a call for a proper assessment of the issues surrounding its use [14].

\section{Use of Serum and Serum Alternatives}

Almost as popular as DMSO is its use with animal sera, notable foetal bovine serum (FBS). Used in concentrations as high as $90 \%$ or, in lower concentrations coupled with culture medium, it has been a staple in the cryopreservation of many banked cell lines. The use of FBS in the development of clinical therapies has been questioned on both microbiological and immunogenic grounds. However, it is currently still permitted as an excipient in the production of cellular therapy products despite widespread beliefs to the contrary [46]. Mendicino et al. [12] found that the majority of MSC-based regulatory submissions described the use of FBS somewhere in the production chain. Regulatory requirements for its use, including risk assessment, validated viral inactivation steps for bovine viruses, and sourcing from geographically approved prion-free herds have been published by both the EMA and FDA [47, 48].

The development of serum-free and xeno-free culture media has been mirrored by the development of similar 
serum/xeno-free CPAs. Commercially available CPAs, which meet this animal serum-free criterion, have been available for some time. The proprietary nature of these commercial offerings makes a detailed risk assessment of the CPA and its components impossible. However, the FDA has allowed suppliers to submit confidential information on their CPA in the form of a drug master file (DMF). Use of a CPA with a DMF does not in itself represent regulatory approval, but it can be used in the submission of a cellular therapy for regulatory approval if cross-referenced in the application. Examples of commercially available CPAs, some with FDA DMFs, can be found in Table 1.

The use of serum substitutes, in both commercial and in self-formulated CPAs, has long been the case. For many years, human albumin solution has been used as an excipient in the cryopreservation of PBSCs in DMSO. More recently, human platelet lysate has been used successfully as an excipient with DMSO in the cryopreservation of adipose-derived stem cells [49]. Examples of commercially available human platelet lysates can be found in Table 1.

\section{Use of "Intracellular-Type" Storage Solutions}

An alternative to the media, serum, and serum substitutes used as vehicle solutions for the CPA are hypothermic storage solutions. Media and physiologic buffers (with/without serum) have often been used as vehicle solutions for CPAs. These "extracellular-type" solutions mimic the ionic composition of interstitial fluids at normothermic temperature. However, when temperatures are lowered below physiological temperatures, "extracellular-type" solutions no longer balance ionic changes or provide sufficient buffering capacity for the changed conditions. The use of "intracellular-type" solutions including Unisol, Eurocollins, and HypoThermosol (Table 1) have been shown to improve cryopreservation outcomes compared to the same CPAs in "extracellular-type" vehicle solutions $[50,51]$.

\section{Self-Formulated CPAs}

The availability of CE-marked, sterile CPAs such as DMSO (Table 1) and appropriate vehicle solutions means that self-formulated cryoprotectant solutions can be prepared in-house. The use of self-formulated CPAs, the practice generally adopted in a research environment, while potentially advantageous during the optimisation phase of the cryoprotection regimen, allowing as it does for precise compositional knowledge, may nevertheless present problems downstream. Additional resources will be required in validating the preparation step and continued quality control and microbiological testing to assure sterility will be needed for each batch of prepared CPA. This may outweigh the cost of utilising commercially available alternatives.

\section{Freezing}

In the context of this paper, slow cooling may be defined as those cooling rates achievable with PCDs and some CRFs. The range for these non- $\mathrm{LN}_{2}$ cooled devices is $\leq 2{ }^{\circ} \mathrm{C} / \mathrm{min}$. $\mathrm{LN}_{2}$-cooled CRFs can attain cooling rates up to around $30^{\circ} \mathrm{C} / \mathrm{min}$ which, again in the context of this paper, might be considered as an intermediate or rapid cooling rate.

Cooling an aqueous solution below its equilibrium freezing point will, at some point, induce water to form ice. Spontaneous ice nucleation is a stochastic event which can take two forms: homogeneous nucleation (occurring at temperatures below $-35^{\circ} \mathrm{C}$ ) and heterogenous nucleation (a surface-catalysed event occurring at temperatures between about -5 and $-20^{\circ} \mathrm{C}$ ). In practice, in cryopreserved system, nucleation is heterogeneous in nature [52].

In cell suspensions, even when the cell concentration is considerably higher than those generally encountered during cell banking, nucleation will generally occur in the much larger extracellular compartment resulting in an osmotic gradient being imposed on the cells as ice forms and salts in the residual liquid phase are concentrated. Cells will respond to the osmotic disequilibria in one of two ways - either by water movement out of the cell or by intracellular nucleation of ice. The route to re-establishing osmotic equilibrium is dependent on a number of factors including water permeability of the cell membrane, the cell surface/volume ration, and the rate of change of temperature: sufficiently slowly and cells will re-equilibrate by shrinking; too rapidly and the cells will supercool and intracellular ice will form [18].

\section{Optimum Cooling Rate}

The addition of a CPA to the system will predominantly protect cells, as freezing progresses, from damage associated with the increasing solute concentration of the residual liquid phase experienced over the temperature range of -10 to $-40{ }^{\circ} \mathrm{C}$. Cooling at a rate that minimises exposure time over this range will improve cell survival. On the other hand, the probability of intracellular ice formation (IIF) is increased by increasing the cooling rate. Thus, the cooling rate that produces maximal survival is dependent not only on biophysical parameters specific to the cell type but also on the type and concentration of the $\mathrm{CPA}$. An examination of survival curve versus cooling rate for a range of cell types will show not only that cell survival is a balance between the opposing forces of solute injury and IIF, but that an optimal cooling rate can be defined for any given cell type $[15,16]$. Moreover, such optimal cooling rates will vary widely depending on cell type.

On the basis of such survival curves, slow cooling can be defined as any cooling rate under which the cell can 
Table 1. Commercially available CPAs and excipients ${ }^{\mathrm{a}}$

\begin{tabular}{|c|c|c|c|}
\hline CPA & Supplier & Comments & Web address \\
\hline \multicolumn{4}{|c|}{ Dimethyl sulphoxide (DMSO) } \\
\hline BloodStor $^{\circledR} 100$ & $\begin{array}{l}\text { Stem Cell } \\
\text { Technologies }\end{array}$ & $\begin{array}{l}>99 \% \text { DMSO, meets USP, manufactured under } \\
\text { cGMP quality system compliant to } 21 \text { CFR } 820\end{array}$ & www.stemcell.com \\
\hline Cryopure $^{\mathrm{TM}}$ & OriGen Biomedical & $\begin{array}{l}>99 \% \text { DMSO, meets USP and EP, sterile, aseptic } \\
\text { filtered, CE marked under EU Directive 93/42/EEC }\end{array}$ & www.origen.com \\
\hline cGMP CryoSolutions $^{\mathrm{TM}}$ & Akron Biotech & $\begin{array}{l}>99 \% \text { DMSO, meets USP, EP and JP, sterile, meets } \\
\text { cGMP guidelines for ancillary materials (USP 1043) }\end{array}$ & www.akronbiotech.com \\
\hline Cryosure-DMSO & $\begin{array}{l}\text { WAK-Chemie } \\
\text { Medical GmbH }\end{array}$ & $\begin{array}{l}>99 \% \text { DMSO, meets USP and EP, sterile } \\
\text { mycoplasma-free, aseptic filled under GMP, CE } \\
\text { marked under EU Directive 93/42/EEC }\end{array}$ & www.wak-chemie.net \\
\hline \multicolumn{4}{|c|}{ Other cryoprotectant solutions } \\
\hline CryoStem $^{\mathrm{TM}}$ & Biological Industries & $\begin{array}{l}\text { Chemically defined, xeno-free, protein-free, } \\
\text { containing DMSO and methylcellulose. Sterile, } \\
\text { manufactured under ISO13408 in cGMP facility, CE } \\
\text { marked for use as an ancillary material in cell and } \\
\text { tissue-based therapies }\end{array}$ & www.bioind.com \\
\hline CryoStor $^{\circledR}$ & $\begin{array}{l}\text { StemCell } \\
\text { Technologies / } \\
\text { BioLife Solutions }\end{array}$ & $\begin{array}{l}\text { Chemically defined, serum-free, animal component- } \\
\text { free containing DMSO (2, } 5 \text { and } 10 \% \text { versions). } \\
\text { Sterile, meets USP, cGMP manufactured under } 21 \\
\text { CFR } 820 \text { compliant quality system, Drug Master File } \\
\text { registered with FDA }\end{array}$ & $\begin{array}{l}\text { www.stemcell.com / } \\
\text { www.biolifesolutions.com }\end{array}$ \\
\hline Stem-CellBanker ${ }^{\circledR}$ & Amsbio / Zenoaq & $\begin{array}{l}\text { Available in DMSO and DMSO-free formulations, } \\
\text { chemically defined serum-free, xeno-free, meets USP } \\
\text { and EP, GMP manufactured, Drug Master File } \\
\text { registered with the FDA (MF\# 15785) }\end{array}$ & $\begin{array}{l}\text { www.amsbio.com / } \\
\text { www.zenoaq.jp }\end{array}$ \\
\hline
\end{tabular}

Vehicle solutions and alternatives to serum

HypoThermosol ${ }^{\circledR}$ FRS BioLife Solutions Intracellular-type hypothermic storage solution.

www.biolifesolutions.com Serum-free, protein free, sterile, meets USP, cGMP manufactured under 21 CFR 820 compliant quality system, Drug Master File registered with FDA

\begin{tabular}{|c|c|c|c|}
\hline $\begin{array}{l}\text { PLTGold }^{\circledR} \\
\text { (Clinical Grade) }^{\text {(Clina }}\end{array}$ & Biological Industries & $\begin{array}{l}\text { Human platelet lysate, serum-free, xeno-free, } \\
\text { heparin-free supplement. GMP-manufactured. US } \\
\text { donors meeting AATB / FDA eligibility standards. } \\
\text { Drug Master File registered with the FDA }\end{array}$ & www.bioind.com \\
\hline nLiven $\mathrm{PR}^{\mathrm{TM}}$ & Cook Regentec & $\begin{array}{l}\text { Human platelet lysate. Sterile, mycoplasma-free, } \\
\text { heparin-free, validated pathogen reduction process, } \\
\text { GMP compliant, US donors meeting AATB / FDA } \\
\text { eligibility standards }\end{array}$ & www.cookregentec.com \\
\hline GMP PLUS ${ }^{\mathrm{TM}}$ & Compass Biomedical & $\begin{array}{l}\text { Human platelet lysate. Serum-free, xeno-free, sterile, } \\
\text { mycoplasma-free, heparin-free, available in bags, } \\
\text { prepared under cGMP, US donors from FDA- } \\
\text { registered blood banks. Drug Master File registered } \\
\text { with the FDA }\end{array}$ & www.compassbiomed.com \\
\hline
\end{tabular}

a The list is not intended to be definitive. All information is taken from supplier websites. Only CPAs indicated as intended for use in therapeutic applications are listed.

respond to the rate of change in temperature by water efflux, while rapid cooling can be loosely defined as that where IIF predominates. This emphasises the contextual nature of the terms "slow" and "rapid" cooling.

\section{Supercooling: An as Yet Uncontrolled Variable}

Of all the events occurring during cryopreservation, supercooling is the least controlled [53]. Supercooling (or undercooling) is the temperature difference between the equilibrium melting point of the system and the temper- 
ature at which nucleation occurs. The degree of supercooling can be highly variable between samples cooled during the same cooling cycle with uncontrolled supercooling leading to sample-to-sample variation in postthaw cellular viability and function which may impact on regulatory requirements for process standardisation and consistency of outcomes. Nucleation, under conditions where a significant degree of supercooling has taken place, will lead to the rapid crystallisation of ice which may result in cellular damage from IIF. Moreover, the large release of latent heat will drive the system temperature back toward the equilibrium melting point and may lead to an extended isothermal plateau which, if externally applied cooling is continued, will lead to an increasing temperature differential between the sample and its surroundings. This will lead to rapid, non-optimal cooling of the system once the latent heat has been evolved. The institution of a programmed sub-zero hold in many CRF protocols is to allow for the release of this latent heat and prevent rapid, uncontrolled sample cooling.

Controlled ice nucleation has been shown to be beneficial in a large number of cell types including MSCs [54] and is used routinely in the field of in vitro fertilisation. However, its application within biobanking and the field of cellular therapies has been largely overlooked. This may well be because the methods for inducing nucleation in samples: "seeding" with ice, rapid temperature ramping, electro-freezing, pressure, vibration and ice nucleating agents are not only difficult to standardise or incorporate routinely into freezing equipment but may not be compatible with Good Manufacturing Practice (GMP) requirements.

GMP compliant ice-nucleating agents have been under development for some time. IceStart ${ }^{\mathrm{TM}}$ (www.asymptote.co.uk), a novel inert nucleating material originally available as beads, has recently been incorporated into a multi-well plate format for use in high-throughput screening. However, its compatibility with cGMP processes has not as yet been reported for any cellular therapy product.

\section{Passive Cooling Devices versus CRFs}

Devices for freezing cells fall into two types: PCDs and CRFs. Commercially available PCDs, in which the recommended conducting medium is isopropanol (Nalgene $^{\circledR}, \mathrm{Mr}$ Frosty ${ }^{\mathrm{TM}}$ ) or a high-density insulating foam incorporating a heat sink device (CoolCell ${ }^{\circledR}$, www.biocision.com), have been designed to achieve cooling rates of approximately $1{ }^{\circ} \mathrm{C} / \mathrm{min}$ between about -10 and $-40^{\circ} \mathrm{C}$ (Fig. 1A). This is achieved by placing the container inside a $-80^{\circ} \mathrm{C}$ refrigerator. Nucleation in these devices is uncontrolled and achieving cooling rates other than that intended for the device is not easily, or consistently, achievable. Though the CoolCell ${ }^{\circledR}$ allows the freezing of both cryovials and cell therapy containers such as the Crystal Zenith vial, the Mr Frosty device is restricted to standard cryovials. However, both devices are limited in the quantity of cryovials that can be frozen in the device at any one time (6-12 vials/CoolCell ${ }^{\circledR}$ and 18 vials/Mr Frosty). A larger capacity CoolCell ${ }^{\circledR}$, the FTS30, provides increased capacity but at the expense of a lower than advertised cooling rate, over the range -10 to $-40^{\circ} \mathrm{C}$ (Fig. 1B).

From a GMP perspective, low-cost, PCDs present some additional complications. Unless modified, they do not allow for temperature monitoring during the freezing process, nor do they provide a thermal profile for quality assurance purposes. Moreover, the cold source must also be validated to demonstrate ultra-low temperature uniformity and stability at the set temperature, while security during the cooling cycle must be assured to prevent thermal transients occurring due to unauthorised access to the $-80^{\circ} \mathrm{C}$ refrigerator. A small dedicated, validated, temperature-monitored, under-bench $-80^{\circ} \mathrm{C}$ freezer is often the best way to achieve the required level of control. The PCDs should also be validated to demonstrate compliance with the stated cooling rate.

The Mr Frosty in particular relies on close adherence to the instructions for use to achieve its specified cooling rate. Under conditions where ultra-low temperature freezer space is limited, adherence to these instructions may be difficult and stacking of containers is not unknown. However, this will lead to a significant lowering of the cooling rate (Fig. 1C) and should be avoided. Partial loading of the PCD should also be avoided as this is likely to cause an increase in the cooling rate of up to $30 \%$ (data not shown).

Automated CRFs fall into two main types: solenoid activated, $\mathrm{LN}_{2}$-fed systems (e.g., Kryo 560 series, www.planer.com; Cryomed series, www.thermofisher.com; 2101 series, www.custombiogenics.com) and Stirling cycle, $\mathrm{LN}_{2}$-free, heat-pump-driven systems (e.g., Viafreeze, www.asymptote.co.uk; Cryocell, www.strexcell.com). All these systems are programmable and capable of multistep cooling profiles and most allow freezing of a wide variety of vials and bags.

The $\mathrm{LN}_{2}$-fed systems are capable of controlled cooling at rates up to around $30^{\circ} \mathrm{C} / \mathrm{min}$, though faster rates are possible. In operation, they can attain an end-point temperature well below $-100^{\circ} \mathrm{C}$. They rely on vaporisation of $\mathrm{LN}_{2}$, in burst into the cooling chamber, which is then exhausted to the outside via an external port. This presents problems for use within a cleanroom from both particulates and microorganisms present in the nonsterile $\mathrm{LN}_{2}$. This may be overcome through porting the gas out of the cleanroom or transferring the cryovials to an adjacent area for freezing. However, the construction of the chamber often results in the collection of water condensate within it, which is not easily removed, and 
Fig. 1. Typical cooling curves for PCDs. PCDs were operated according to the manufacturer's instructions. Thin wire thermocouples (TWTc) were inserted through adapted PCD lids into the centre of specially adapted cryovials containing $1 \mathrm{~mL}$ of CPA (10\% DMSO in FBS). These were then placed in the PCD. The remaining spaces were filled with cryovials containing $1 \mathrm{~mL}$ of CPA. All cryovials were equilibrated at $20{ }^{\circ} \mathrm{C}$ for between 20 and $30 \mathrm{~min}$ before transfer of the PCD to a monitored, controlled-access $-80^{\circ} \mathrm{C}$ freezer. The temperature was recorded every $6 \mathrm{~s}$ for $5 \mathrm{~h}$ using a multi-channel datalogger. The illustrations show position of the TWTc. Mean cooling rate (MCR) between -10 and $-40^{\circ} \mathrm{C}$ was based on the number of technical replicates per experiment shown on the graph. A minimum of 3 experiments were performed in each group. A PCDs Mr Frosty and CoolCell 12. B CoolCell FTS30 (note reduced cooling rate compared to the CoolCell 12). C Stacked PCDs. Two Mr Frostys were treated as above but stacked on top of each other and placed within the same compartment of the $-80^{\circ} \mathrm{C}$ freezer. Of the 4 TWTc shown, two were housed in the upper and two in the lower PCD. Note the significantly reduced cooling rate for cryovials in the upper PCD.
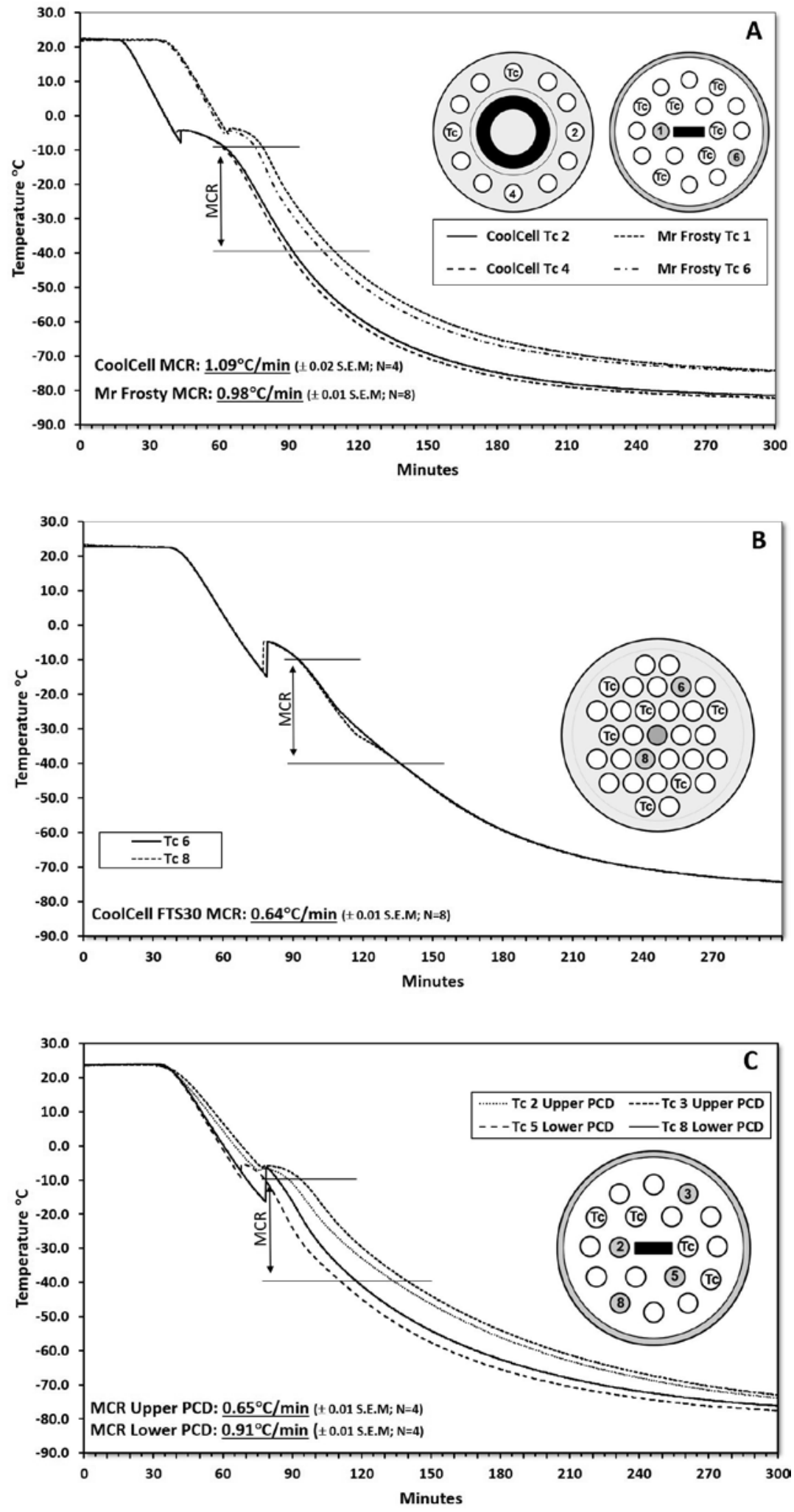

which may act as a potential source of microbial growth. Where possible the primary container should be overwrapped before freezing to prevent potential contamination.
The Stirling cycle CRFs have the advantage that they can be used within a cleanroom environment and are available in configurations that cater for a range of cell bank sizes in a variety of formats. Moreover, unlike $\mathrm{LN}_{2}$ - 
fed systems, which generally operate on a 30- to 50- $\mathrm{LN}_{2}$ supply, these electrically driven systems can maintain the desired end-point temperature indefinitely. They too can reach sub-zero temperatures of around $-100{ }^{\circ} \mathrm{C}$. The mode of heat removal requires close contact between the cryovial/bag and the freezing plate and though these plates are user-changeable, they need to be machined to fit exactly the chosen cryovial/bag. A limitation of these systems is that cooling rates for the samples are restricted to approximately $2{ }^{\circ} \mathrm{C} / \mathrm{min}$ and below, so cell types with more rapid optimum cooling rates are not suited to these systems.

An alternative to the $\mathrm{LN}_{2}$ and Stirling cycle engine CRFs is the Thermogenesis BioArchive ${ }^{\circledR}$ system (www. cescatherapeutics.com). This is a combined, robotic CRF and $\mathrm{LN}_{2}$ storage vessel used mainly for clinical cord blood banking. The device utilises small, closed-system bags held in metal cassettes which are cooled in the gas phase above the $\mathrm{LN}_{2}$ storage medium. Control of cooling rate is via a computer-controlled fan which blows the ultra-cold gaseous nitrogen across the cassette. Once frozen, the cassettes are automatically lowered into storage slots and stored under $\mathrm{LN}_{2}$.

A recent novel CRF (Cells Alive System, ABI Corp., Japan) has been used to cryopreserve pluripotent stem cells [55]. This system incorporates an oscillating magnetic field and, although there is some discussion over the way in which the system improves cryopreservation outcomes [56], a hypothesis has been recently advanced which suggests a mode of action [57]. In spite of these alternatives, the $\mathrm{LN}_{2}$-fed and Stirling cycle-driven CRFs remain the main choices for larger-scale cryopreservation of cellular therapies.

\section{Storage and Transportation}

With the exception of North America, where cryopreserved red blood cells for clinical use are stored at $-80^{\circ} \mathrm{C}$ (though not without adverse changes to the red blood cell [58]), it is generally accepted that storage at $-80^{\circ} \mathrm{C}$, and above, leads to progressive deterioration and loss of viability. In comparison to storage below $-135^{\circ} \mathrm{C}$, it has been shown to be inferior for long-term storage of both cells and tissues $[59,60]$. Significant deterioration in viability has been noted in peripheral blood mononuclear cells after 14 months of storage at $-80^{\circ} \mathrm{C}$ [61] and in PBSCs, where clonogenic capacity was lost over periods of as litthe as 5 months [62]. Recently, the use of Ficoll 70 in the cryoprotectant medium has been shown to extend the $-80^{\circ} \mathrm{C}$ storage period in human pluripotent stem cells to at least 1 year [63]).

Nevertheless, for the majority of cellular therapies, long-term storage with minimal deterioration of master and working cell banks, as well as the final product, will require storage well below the glass transition temperature $\left(\mathrm{T}_{\mathrm{g}}\right)$ of the system in question. This is generally taken to be the $\mathrm{T}_{\mathrm{g}}$ of water (approximately $-135^{\circ} \mathrm{C}$ ) and is achieved routinely by storage in or above $\mathrm{LN}_{2}$. While storage under $\mathrm{LN}_{2}$ provides a stable ultra-low temperature, contamination issues [64] and a well-documented case of hepatitis $\mathrm{B}$ transmission via $\mathrm{LN}_{2}[65]$ have led to a change in custom, such that storage in the gas phase above $\mathrm{LN}_{2}$ is now the accepted, and recommended, practice.

The argument against storage in the gas phase was based on the thermal instability encountered in olderstyle storage freezers; where temperatures of $-100^{\circ} \mathrm{C}$ at the top of the inventory system were not uncommon. The use of a copper heat shunt or thermally conductive racking system are common methods of reducing these thermal gradients. Isothermal vessels, in which the $\mathrm{LN}_{2}$ is held in an external jacket surrounding the storage compartment, can provide a stable ultra-low temperature provided that a continuous, on-demand supply of $\mathrm{LN}_{2}$ is available to the freezer. More recently, a change in the design of $\mathrm{LN}_{2}$ freezers has largely eliminated these thermal gradients, with stable below-lid temperatures of $-180^{\circ} \mathrm{C}$ easily achievable (e.g., Chart MVE High Efficiency Series, www.chartindustries.com).

The cost and complexity of delivering an on-demand supply of $\mathrm{LN}_{2}$ can be significant and the availability of reliable ultra-low temperature mechanical freezers capable of maintaining stable temperatures down to $-150{ }^{\circ} \mathrm{C}$ provides a feasible alternative to $\mathrm{LN}_{2}$ storage. Studies on PBSCs have shown comparability, at least in the mediumterm (up to 5 years), between cells stored in a mechanical freezer and those stored in gas phase $\mathrm{LN}_{2}$ [66].

When choosing between $\mathrm{LN}_{2}$ and mechanical refrigeration, consideration should be given to the additional cost required to remove waste heat produced by the mechanical freezers and the potential temperature transients experienced by the product during access to the freezer. Though the latter also occurs during access to $\mathrm{LN}_{2}$ freezers, the lower storage temperature obtained in the $\mathrm{LN}_{2}$ freezer provides some temperature "buffering" during access.

One area of low-temperature storage that has received little attention until recently is the thermal history of the stored product and in particular the thermal transients experienced during its storage lifetime. Thermal transients occur to the samples when racks and sample boxes are removed from the stable, low-temperature environment of the freezer for audit or pick-and-dispatch. The thermal transient experienced by any given sample will depend not only on the length of time that it is outside of its storage environment but also on the position of the sample in the sample container and the insulation given to it by surrounding samples (Fig. 2). In addition, samples in surrounding racks will experience thermal transients 
Fig. 2. Effect on the temperature of cryovials, located in different positions within a cryovial box, of removing the inventory tower, containing the cryobox, from $\mathrm{LN}_{2}$ storage. Thin wire thermocouples (TWTc) were inserted into adapted cryovials containing $1 \mathrm{~mL}$ of CPA and placed either at the periphery or centre of a $5 \times 5$ cryovial box. The boxes were either filled to capacity or remained empty. Temperature was recorded every $60 \mathrm{~s}$. The cryovials rewarmed at rates between $6.8^{\circ} \mathrm{C} / \mathrm{min}$ and $11.5^{\circ} \mathrm{C} / \mathrm{min}$ depending on their location in the box and the degree of insulation afforded by surrounding cryovials. The illustrations show the position of TWTc.

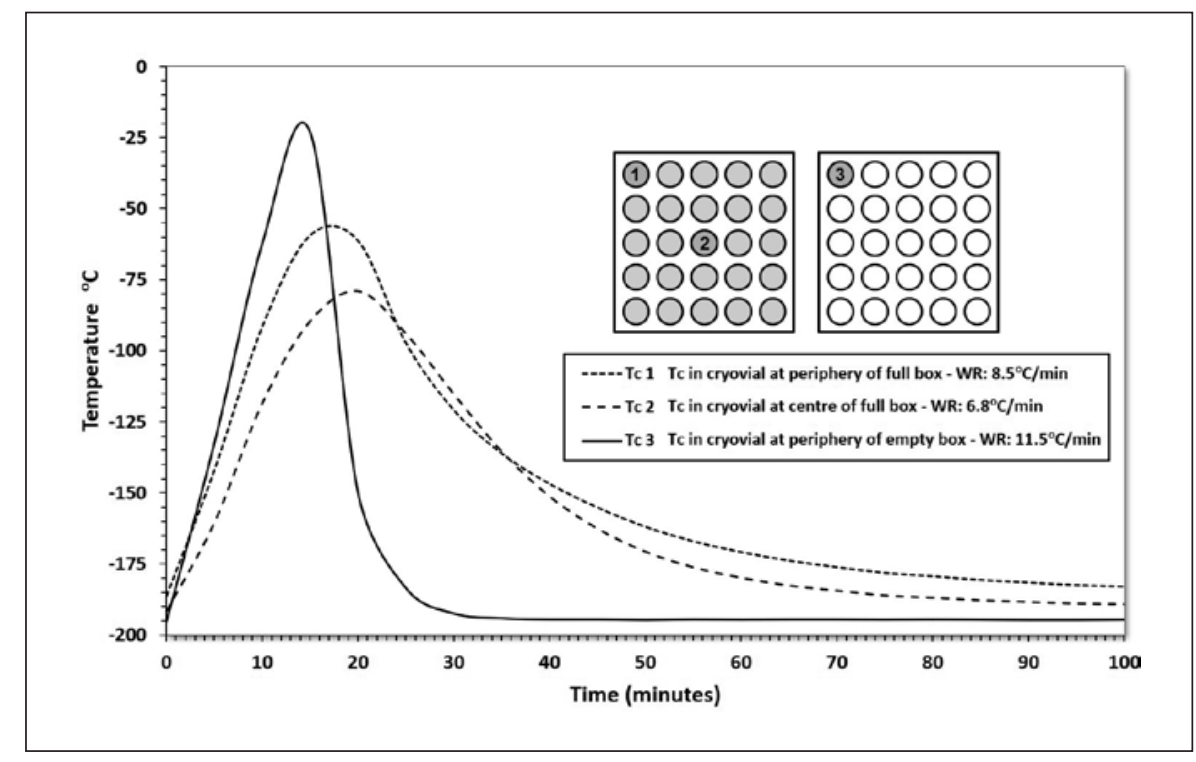

as the now-warmed rack is returned to the freezer (data not shown). Thus, samples will experience multiple thermal transients over their lifetime as surrounding material is added to and withdrawn from the freezer.

The effect of thermal transients during storage has been the subject of a number of recent studies which imposed temperature fluctuations on frozen stored peripheral blood mononuclear cells [67] or placental MSCs [68]. In these studies, designed to mimic events in busy biorepositories, the cells were exposed to multiple temperature cycles between $\mathrm{LN}_{2}$ gas phase temperatures and temperatures as high as $-60^{\circ} \mathrm{C}$. Reduced recovery and functionality was detectable, compared to stable gas phase storage, when the number of cycles was $>20$ and/or the peak temperature was higher than $-100^{\circ} \mathrm{C}$. Similar effects of cycling over the glass transition temperature have been shown to affect tissues structure and performance as well [69].

Devices, which limit thermal transients by maintaining the racks within a low temperature shroud during access, are becoming available for both cryovials and bags (e.g., Biostore ${ }^{\mathrm{TM}} \mathrm{III}$, www.brookeslifesciences.com). However, they are not currently capable of being retro-fitted to existing $\mathrm{LN}_{2}$ storage freezers, nor do they protect any other cryovials held in the same cryobox during the picking process. Whilst such devices may offer some advantages, separation of master cell banks from stocks likely to see frequent activity should be considered to reduce or avoid thermal transients.

\section{Disaster Recovery}

Off-site, secondary storage of material for disaster recovery purposes is considered best practice and may be a regulatory requirement where material is prepared for clinical applications. The material will generally come from the master cell bank but earlier, precursor stocks may also be held for such purposes as well as archive material from prepared lots or batches. Many biobanks and biorepositories offer such facilities under licence from the respective regulatory authorities. Before choosing a facility, it should be assessed for compliance with regulatory requirements as part of the selection process. Documentary evidence that storage freezers have been validated prior to use should be available for review and freezers should be continuously temperature-monitored with temperature output provided regularly to the user under a service level agreement. The facility should operate under a robust quality management system with documented procedures for investigating and reporting adverse events to the end-user. Access to the facility and the storage freezers should be restricted and controlled.

\section{Transportation}

Sample integrity and temperature stability also need to be considered during transportation whether this be within the facility (to limit so-called air time between removal from storage and thawing) [70] or during shipping between sites. The options are mainly limited to dry ice and $\mathrm{LN}_{2}$, though portable cryocoolers utilising the same principle as the Stirling cycle CRFs are available (e.g., Stirling Shuttle ${ }^{\mathrm{TM}}$, www.stirlingultracold.com).

For transportation at approximately $-196^{\circ} \mathrm{C}$ (essential to prevent de-vitrification of meta-stable vitrified material), $\mathrm{LN}_{2}$ dry shippers, in which the liquid is absorbed into an inert molecular-sieve material, are available, which will hold temperature for up to 14 days if fully charged. Coming in a variety of sizes, some are suitable for intralaboratory use (e.g., MVE Minimoover, www.chartindustries. com). Other systems, also utilising $\mathrm{LN}_{2}$, have been de- 
signed specifically for movement of samples around the laboratory (Cryopod ${ }^{\mathrm{TM}}$, www.brookeslifesciences.com).

Transporting frozen cells on dry ice, in insulated boxes at $-80^{\circ} \mathrm{C}$, is perhaps the commonest method of transporting frozen cells. Unlike dry shippers, thermal transport boxes generally only maintain temperature for 24$48 \mathrm{~h}$, depending on the quality of insulation and amount of dry ice used, though some boxes provide temperature stability out to $120 \mathrm{~h}$ (e.g., PharmaTherm dry ice range, www.intelsius.com).

As important as maintenance of a stable temperature is the ability to provide evidence of it, both to regulators and to the end-user. Many of the dry shippers are available with temperature-logging lids and small portable temperature loggers are available for use with both dry shippers and dry ice transport boxes. Chemical warning devices (e.g., Cryoguard ${ }^{\mathrm{TM}}$ thermal exposure indicators, www.cryoguard.com) can be used in conjunction with such data-logging systems to provide visual evidence to end-users that the product has maintained the desired temperature during shipment.

Whilst there is no expectation that thermal transport boxes will be returned by the recipient, this is not the case for expensive dry shippers. The non-return of a dry shipper, or its damage in transit will have a significant financial impact. Therefore, if the decision has been made to distribute material using dry shippers, consideration should be given to using third-party logistics companies which provide temperature-logged dry shipper packages (e.g., Cryoport Express ${ }^{\circledR}$, www.cryoport.com). This will help remove some of the logistic and administrative burden associated with shipping in dry shippers while also helping ensure compliance with complex national and international shipping regulations (for detailed information see Simione and Sharp [71]).

\section{Thawing and Elution of CPA}

As with cooling rate, warming rate can have a significant impact on cellular recovery, with cells damaged through the use of inappropriate thawing and CPA elution protocols. Rapid rewarming is important. Not only does it reduce exposure time to damaging solute concentrations as ice melts during rewarming, but it also avoids potential damage caused by intracellular ice recrystallisation. Here, the rate necessary to avoid recrystallisation is at least an order of magnitude greater than the minimum cooling rate leading to significant IIF [13]. The warming rate is of particular importance when considering transfer of the cells from frozen storage to the area where they are to be thawed. Even short periods of air time, during which the cells are undergoing passive rewarming at a relatively slow rate, may induce cellular damage particularly from IIF.

Practical Aspects in the Cryopreservation of Cellular Therapies
The simplest and easiest method of achieving rapid warming has been the use of a $37^{\circ} \mathrm{C}$ water bath. From the laboratory, to cryopreserved tissue allografts in theatre and point-of-care thawing of haematopoietic stem cells at the bedside [72], the almost universal use of this technology has led to most cryopreservation protocols being optimised against the back-drop of a warming rate achieved through its use. However, the use of such a method within a GMP environment raises issue of potential contamination and logistical problems in maintaining sterility. Moreover, the potential for thermal runaway once the system has melted, with the attendant danger of exposing cells to the CPA at elevated temperatures, is problematic.

The rewarming process itself is non-linear, with an initial rapid warming rate giving way to a much slower rate due to the large thermal input (the latent heat of fusion) required at the phase transition. The need to drive this process as rapidly as possible requires elevated thawing temperatures which must be balanced against the danger of thermal runaway. For this reason, standard practice is to agitate the sample during thawing to reduce thermal gradients and to remove it from the water bath, once visual inspection shows dissipation of the last remnants of the ice ball. Samples should be cold not warm at the end of thawing.

A number of strategies have been adopted to circumvent the use of a water bath. Typical warming rates produced by some of these alternatives are shown in Table 2 . Warming rates are shown over three ranges: from -150 to $-80^{\circ} \mathrm{C}$ (i.e., over $\mathrm{T}_{\mathrm{g}}$ and ice recrystallisation), from -80 to $-20^{\circ} \mathrm{C}$ (exposure to elevated solute concentrations), and from -20 to $0^{\circ} \mathrm{C}$. Passive warming in air at the bench, or in a $37^{\circ} \mathrm{C}$ incubator, are unsuitable alternatives and are likely to lead to reduced viability [70]. Whilst replacing the water in a water bath with thermally conductive beads produces a more rapid rate of warming, it is not reliable due to temperature gradients through and across the bath (data not shown). The use of a CoolRack ${ }^{\mathrm{TM}}$ (www.biocision.com) made from thermally conductive material, which is pre-warmed and held within a $37^{\circ} \mathrm{C}$ incubator, provides warming rates similar to those provided by the Biocision ThawStar ${ }^{\mathrm{TM}}$ (www.asterobio.com), an automated, dry-thawing system designed to provide reproducible, rapid warming.

From a quality assurance perspective, automated systems that provide a standardised, reproducible warming rate and, in some cases, a temperature read-out of the thawing process for purposes of traceability, are preferred. In addition to the ThawStar ${ }^{\mathrm{TM}}$ which is available in a variety of vial formats, automated, data-logging systems are available from Cook Regentec (CellSeal ${ }^{\circledR}$, www. cookregentec.com) and promised by GE Healthcare (VIAThaw SC). 
Table 2. Warming rates attained using different thawing devices ${ }^{\mathrm{a}}$

\begin{tabular}{llrr}
\hline Rewarming method & \multicolumn{2}{l}{ Mean warming rate, ${ }^{\circ} \mathrm{C} / \mathrm{min} \pm \mathrm{SEM}$} & \\
\cline { 2 - 3 } & -150 to $-80^{\circ} \mathrm{C}$ & -80 to $-20^{\circ} \mathrm{C}$ & -20 to $0^{\circ} \mathrm{C}$ \\
\hline $37^{\circ} \mathrm{C}$ stirred water bath & $348.2 \pm 17.4$ & $117.5 \pm 17.4$ & $14.3 \pm 1.1$ \\
$37^{\circ} \mathrm{C}$ incubator $\left(+\mathrm{CoolRack}{ }^{\mathrm{TM}} \mathrm{CFT} 30\right)$ & $168.0 \pm 6.7$ & $55.9 \pm 0.4$ & $7.2 \pm 0.2$ \\
Biocision ThawStar $^{\mathrm{TM}}$ (from $-193^{\circ} \mathrm{C}$ ) & $164.7 \pm 3.4$ & $46.7 \pm 0.9$ & $15.2 \pm 0.7$ \\
Biocision ThawStar $^{\mathrm{TM}}$ (from $-79^{\circ} \mathrm{C}$ ) & & $41.3 \pm 1.1$ & $14.1 \pm 0.6$ \\
$37^{\circ} \mathrm{C}$ bead bath & $118.0 \pm 1.5$ & $35.4 \pm 0.3$ & $4.3 \pm 0.2$ \\
$20^{\circ} \mathrm{C}$ bench (static air) & $59.5 \pm 2.6$ & $18.6 \pm 0.3$ & $2.2 \pm 0.1$ \\
$37^{\circ} \mathrm{C}$ incubator (circulating air) & $54.1 \pm 2.6$ & $23.2 \pm 0.5$ & $3.9 \pm 0.1$ \\
\hline
\end{tabular}

\footnotetext{
a Specially adapted cryovials housing thin wire thermocouples and containing $1 \mathrm{~mL}$ of CPA were frozen and stored in a charged dry shipper at $-193^{\circ} \mathrm{C}$ for $24 \mathrm{~h}$ before thawing under one of the above thawing conditions. Temperature was recorded every $500 \mathrm{~ms}$. Mean warming rate (WR) was based on 4 technical replicates per experiment and a minimum of three experiments per device. Samples thawed in the Biocision ThawSTAR ${ }^{\mathrm{TM}}$ were $^{-}$ thawed from both dry shipper and dry ice temperatures according to the manufacturer's instructions. The Biocision CoolRack ${ }^{\mathrm{TM}}$ was prewarmed overnight before use and its temperature and that of the $37^{\circ} \mathrm{C}$ incubator measured between cryovial warming runs to ensure that temperature remained constant. Note similarity in WR for bench and incubator thawed samples which is related to the poor heat transfer properties of air. More rapid conductive rewarming in the Biocision CoolRack ${ }^{\mathrm{TM}}$, compared to passive warming in the incubator, is the result of the improved heat transfer properties of this device.
}

Dry-thaw systems for bags have been common for some time in the blood bank sector and, in addition to the devices used there, automated thawing systems, similar to those for cryovials are available for frozen bags (VIAThaw CB1000, www.asymptote.co.uk; SmartThaw ${ }^{\mathrm{TM}}$, www.cpsibiotech.com; ThawStar CB, www.astrobio. com). All can be used for point-of-care thawing of haematopoietic cells and other cells frozen in bags and have been shown to provide comparable post-thaw recovery to thawing in a water bath [73].

\section{Elution of CPA}

Once thawed, the cells will again be exposed to the CPA with the attendant danger of chemical toxicity if held at too high a temperature. This can be mitigated by reducing the temperature (i.e., maintain cells at around $4^{\circ} \mathrm{C}$ ), using a lower CPA concentration during freezing (subject to it providing optimal cryoprotection) or eluting it from the system. The danger of over-warming may be more significant where commercially based CPAs utilising "intracellular-type" vehicle solutions are concerned. These are formulated for hypothermic support and cells may be more sensitive to these solutions under post-thaw normothermic culture conditions.

As already discussed, elution of the CPA, if carried out inappropriately, can lead to osmotic shock and loss of viability as cell swell and are ruptured. Single-step elution protocols, such as centrifugation and immediate resuspension in CPA-free medium, should be investigated for their effect on post-thaw viability and consideration should be given to step-wise protocols or the use of "os- motic buffers" (e.g., sucrose, mannitol) to reduce cell swelling during CPA removal.

Automated systems for GMP washing have been described [74]. However, these systems, based on continuous centrifugation or tangential flow filtration, are only suited to concentrating cells from large volumes upstream of the cryopreservation process. Automated washing system for removal of CPA and cellular debris have been described recently [75] but are not yet commercially available (www.closedcellsystems.com).

\section{Use of Additives}

In addition to the incorporation of materials into the CPA to control ice formation, compounds can be added either to the CPA or the post-thaw culture medium to control cryopreservation-induced, delayed-onset cell death through a strategy of targeted apoptotic control [18, 50]. Such compounds include free radical scavengers, ion chelators, and protease inhibitors as well as both caspase inhibitors and Rho-kinase (ROCK) inhibitors which target the apoptotic cascade. Many of these have been shown to reduce cryopreservation-induced apoptosis in PSCs [18] and at least one of these, the ROCK inhibitor Pinacidil, is an FDA-approved compound [76].

\section{Assessment of Viability}

Integral to optimising the cryopreservation process is the application of a reliable and representative set of viability and functional assays which accurately assess the 
state of the cell post-thaw. The timing in application of these assays post-thaw is now seen as crucial, if reliable evaluation of the parameters governing the cryopreservation process is to be achieved. Moreover, the choice of assays should reflect the functional outcomes expected of the cell or cellular therapy and the potential for selection of subpopulations through genomic and epigenetic changes in the surviving cell population $[63,77]$.

Baust et al. [70] have argued for a four-tiered approach to the assessment of viability which encompasses assessment of membrane integrity, molecular (apoptotic/necrotic) mechanisms, functionality (applicable where possible to functions that represent the intended use of the cells) and "biochemical mechanisms" (encompassing genomic, epigenetic and proteomic assays). This tiered approach fits well with the regulatory requirement to demonstrate identity, purity, and stability of cell therapy products [25].

As well as the choice of assay, the time of application is also crucial in providing an accurate picture of postthaw viability. Assessment immediately post-thaw is likely to overestimate cell recovery as a substantial degree of cell death will occur $24-48 \mathrm{~h}$ post-thaw. This delayedonset cell death, a manifestation of apoptotic and necrotic processes, will be missed if viability is assessed immediately post-thaw or after several passages in culture.

The "health" of cells going into the cryopreservation process will affect the post-thaw outcome. Cells stressed by suboptimal culture conditions prior to cryopreservation have been shown to have impaired viability and function post-thaw compared to non-stressed cells [70]. Whilst it is common to use a simple assay such as trypan blue prior to cryopreservation, this alone may not provide sufficient information on the "quality" of the cells, especially in the case of PSCs, where the retention of self-renewal and differentiation capacity are essential. This argues for the application of the tiered approach, or at least a simplified version of it, to cells pre-cryopreservation as well as post-thaw.

An understanding of the assay and the context into which the assay is being applied is also important. Simple assays, such as the membrane integrity assay trypan blue, may under or overestimate viability depending on the fluidity of the membrane post-thaw, the cell type and the length of exposure to the dye. The use of Alamar Blue, a popular non-toxic redox indicator for assaying cellular metabolism (and thus cell survival) can give false results in the presence of reduced glutathione (a component of some hypothermic storage solutions) [78].

\section{Conclusions}

The manufacture and delivery of cellular therapy products will invariably require cryopreservation and frozen storage of cellular starting materials, intermediates and/or final product. Optimisation of culture conditions to provide maximum yield and a consistent end-product is seen as a necessary part of process development and validation, yet often the cryopreservation process remains largely ignored and suboptimal post-thaw viability tolerated, due to the capacity of the remaining viable cells to expand. However, suboptimal cryopreservation not only reduces cell viability but can also lead to batch-tobatch variability and potentially to genetic and epigenetic changes that may compromise the production process, while adverse storage conditions may reduce the effectiveness of the end-product.

Optimisation of the cryopreservation process is thus as essential as optimising culture conditions and attention to all elements in the cold chain is necessary to maintain cell viability and functionality. The need for cellular therapies to meet regulatory requirements means that much of the materials and equipment designed for laboratory use will need to be re-assessed for its fitness-for-purpose. Equipment will require formal validation, while CPAs, other excipients, and consumables will need to be risk assessed for their suitability for use in a therapeutic context. Cryopreservation protocols will need to be designed with both regulatory and end-user needs in mind rather than retrospectively engineered from laboratory protocols unsuited to the final therapeutic application. Developments in container technology, coupled with commercially available GMP-compliant CPAs, new and adapted technologies for freezing and thawing, together with improvements in low-temperature storage and distribution now provide a platform on which optimised cryopreservation protocols can contribute effectively to the future development of cellular therapies.

\section{Statement of Ethics}

The author has no ethical conflicts to disclose.

\section{Disclosure Statement}

The author has no conflicts of interest to declare.

\section{References}

1 Mason C, Dunnill P. A brief definition of regenerative medicine. Regen Med. 2008 Jan; $3(1): 1-5$.

2 House of Lords Science and Technology Committee. Regenerative medicine, HL23, first report of session 2013-14. The Stationary Office; 2013, ISBN 9780108551109.

3 Mount NM, Ward SJ, Kefalas P, Hyllner J. Cell-based therapy technology classifications and translational challenges. Philos Trans R Soc Lond B Biol Sci. 2015 Oct;370(1680): 20150017. 
4 Advanced therapy medicinal products. https://www.ema.europa.eu/en/human-regulatory/overview/advanced-therapy-medicinal-products

5 Cellular therapies. https://www.fda.gov/BiologicsBloodVaccines/CellularGeneTherapyProducts/default.htm

6 Petricciani J, Hayakawa T, Stacey G, Trouvin JH, Knezevic I. Scientific considerations for the regulatory evaluation of cell therapy products. Biologicals. 2017 Nov;50:20-6.

7 European Medicines Agency. Annual report 2017. https://www.ema.europa.eu/documents/annual-report/2017-annual-reporteuropean-medicines-agency_en.pdf

8 Food and Drug Agency. Approved cellular and gene therapy products. https://www.fda gov/BiologicsBloodVaccines/CellularGeneTherapyProducts/ApprovedProducts/default.htm

9 Clinical Trials Database. Available from: https://www.clinicaltrials.gov (using search terms "mesenchymal stem cells" AND "allogeneic" AND "stem cell therapy" AND "human" for MSC trials and search terms "ES cells" OR "embryonic stem cells" OR “iPS cells" OR "induced pluripotent cells" AND "interventional studies" for hESC/iPSC trials). Accessed January 2019.

10 Martin U. Therapeutic application of pluripotent stem cells: challenges and risks. Front Med (Lausanne). 2017 Dec;4:229.

11 Mason C, Brindley DA, Culme-Seymour EJ, Davie NL. Cell therapy industry: billion dollar global business with unlimited potential. Regen Med. 2011 May;6(3):265-72.

12 Mendicino M, Bailey AM, Wonnacott K, Puri RK, Bauer SR. MSC-based product characterization for clinical trials: an FDA perspective. Cell Stem Cell. 2014 Feb;14(2):141-5.

13 Lewis JK, Bischof JC, Braslavsky I, Brockbank KG, Fahy GM, Fuller BJ, et al. The Grand Challenges of Organ Banking: proceedings from the first global summit on complex tissue cryopreservation. Cryobiology. 2016 Apr; 72(2):169-82.

14 Stacey GN, Connon CJ, Coopman K, Dickson AJ, Fuller B, Hunt CJ, et al. Preservation and stability of cell therapy products: recommendations from an expert workshop. Regen Med. 2017 Jul;12(5):553-64.

15 Mazur P. Principles of cryobiology. In: Fuller BJ, Lane N, Benson EE, editors. Life in the frozen state. Boca Raton: CRC Press; 2004. pp. 3-65.

16 Muldrew K, Acker JP, Elliott JAW, McGann LE. The water to ice transition: implications for living cells. In: Fuller BJ, Lane N, Benson $\mathrm{EE}$, editors. Life in the frozen state. Boca Raton: CRC Press; 2004. pp. 67-108.

17 Fahy GM, Wowk B. Principles of cryopreservation by vitrification. Methods Mol Biol. 2015;1257:21-82.

18 Hunt CJ. Cryopreservation: vitrification and controlled rate cooling. Methods Mol Biol. 2017;1590:41-77.

19 Hunt CJ. Cryopreservation of human stem cells for clinical application: a review. Transfus Med Hemother. 2011;38(2):107-23.
20 Rajamani K, Li Y-S, Hseih D-K, Lin S-Z, Harn $\mathrm{H}-\mathrm{J}$, Chiou T-W. Genetic and epigenetic instability of stem cells. Cell Transplant. 2014; 23:417-33.

21 Hotchkiss RS, Strasser A, McDunn JE, Swanson PE. Cell death. N Engl J Med. 2009 Oct; 361(16):1570-83.

22 Hunt CJ, Pegg DE, Armitage SE. Optimising cryopreservation protocols for haematopoietic progenitor cells: a methodological approach for umbilical cord blood. Cryo Letters. 2006 Mar-Apr;27(2):73-86.

23 Mitchell PD, Ratcliffe E, Hourd P, Williams DJ, Thomas RJ. A quality-by-design approach to risk reduction and optimization for human embryonic stem cell cryopreservation processes. Tissue Eng Part C Methods. 2014 Dec; 20(12):941-50.

24 Clarke D, Stanton J, Powers D, Karnieli O, Nahum S, Abraham E, et al. Managing particulates in cell therapy: guidance for best practice. Cytotherapy. 2016 Sep;18(9):106376.

25 Andrews PW, Baker D, Benvinisty N, Miranda B, Bruce K, Brüstle O, et al. Points to consider in the development of seed stocks of pluripotent stem cells for clinical applications: International Stem Cell Banking Initiative (ISCBI). Regen Med. 2015;10(2 Suppl):1-44.

26 Chen HI, Tsai CD, Wang HT, Hwang SM. Cryovial with partial membrane sealing can prevent liquid nitrogen penetration in submerged storage. Cryobiology. 2006 Oct;53(2): 283-7.

27 Woods EJ, Thirumala S. Packing considerations for biopreservation. Transfus Med Hemother. 2011;38(2):149-56.

28 Woods EJ, Bagchi A, Goebel WS, Vilivalam VD, Vilivalam VD. Container system for enabling commercial production of cryopreserved cell therapy products. Regen Med. 2010 Jul;5(4):659-67.

29 Levinson Y, Eylon Y, Heymann A. ZaretskyRits, Karneili O. Foundation Elements for Cell Therapy Smart Scaling. Bioprocess Int. 2015. Available from: https://bioprocessintl. $\mathrm{com} /$ manufacturing/cell-therapies/foundation-elements-for-cell-therapy-manufacturing-smart-scaling/.

30 Amps KJ, Jones M, Baker D, Moore HD. In situ cryopreservation of human embryonic stem cells in gas-permeable membrane culture cassettes for high post-thaw yield and good manufacturing practice. Cryobiology. 2010 Jun;60(3):344-50.

31 Heidemann R, Lünse S, Tran D, Zhang C. Characterization of cell-banking parameters for the cryopreservation of mammalian cell lines in 100-mL cryobags. Biotechnol Prog. 2010 Jul-Aug;26(4):1154-63.

32 Spoerl S, Peter R, Wäscher D, Verbeek M, Menzel H, Peschel C, et al. Long-term experiences in cryopreservation of mobilized peripheral blood stem cells using a closed-bag system: a technology with potential for broader application. Transfusion. 2015 Nov;55(11): 2702-8.

33 Spoerl S, Peter R, Krackhardt AM. Cryopreservation in closed bag systems as an alternative to clean rooms for peripheral blood stem cells. Adv Exp Med Biol. 2016;951:67-76.
34 Sargent B. Direct inoculum of bioreactors with $\mathrm{CHO}$ cells from frozen seed bags to eliminate continual seed trains and improve facility utilization. Blog Post 2017 Jan 24. Available from: https://cellculturedish.com/directinoculum-of-bioreactors-with-cho-cellsfrom-frozen-seed-bags-to-eliminate-continual-seed-trains-and-improve-facility-utilization/.

35 Kuleshova LL, Tan FC, Magalhaes M, Gouk SS, Lee KH, Dawe GS. Effective cryopreservation of neural stem and progenitor cells without serum or proteins by vitrification. Cell Transplant. 2009;18(2):135-44.

36 Nishigaki T, Teramura Y, Suemori H, Iwata H. Cryopreservation of primate embryonic stem cells with chemically-defined solution without Me2SO. Cryobiology. 2010 Apr; 60(2):159-64.

37 Kaindl J, Meiser I, Majer J, Sommer A, Krach F, Katsen-Globa A, et al. Zooming in on cryopreservation of hiPSCs and neural derivatives: a dual-center study using adherent vitrification. Stem Cells Transl Med. 2019 Mar; 8(3):247-59.

38 Elliott GD, Wang S, Fuller BJ. Cryoprotectants: A review of the actions and applications of cryoprotective solutes that modulate cell recovery from ultra-low temperatures. Cryobiology. 2017 Jun;76:74-91.

39 Hunt CJ, Armitage SE, Pegg DE. Cryopreservation of umbilical cord blood: 2 . Tolerance of CD34(+) cells to multimolar dimethyl sulphoxide and the effect of cooling rate on recovery after freezing and thawing. Cryobiology. 2003 Feb;46(1):76-87.

40 Best BP. Cryoprotectant toxicity: facts, issues and questions. Rejuvenation Res. 2015 Oct; 18(5):422-36

41 Pal R, Mamidi MK, Das AK, Bhonde R. Diverse effects of dimethyl sulfoxide (DMSO) on the differentiation potential of human embryonic stem cells. Arch Toxicol. 2012 Apr; 86(4):651-61.

42 Iwatani M, Ikegami K, Kremenska Y, Hattori N, Tanaka S, Yagi S, et al. Dimethyl sulfoxide has an impact on epigenetic profile in mouse embryoid body. Stem Cells. 2006 Nov;24(11): 2549-56.

43 Koike M, Ishino K, Kohno Y, Tachikawa T, Kartasova T, Kuroki T, et al. DMSO induces apoptosis in SV40-transformed human keratinocytes, but not in normal keratinocytes. Cancer Lett. 1996 Nov;108(2):185-93.

44 Windrum P, Morris TC, Drake MB, Niederwieser D, Ruutu T; EBMT Chronic Leukaemia Working Party Complications Subcommittee. Variation in dimethyl sulfoxide use in stem cell transplantation: a survey of EBMT centres. Bone Marrow Transplant. 2005 Oct; 36(7):601-3.

45 Ikeda K, Ohto H, Okuyama Y, Yamada-Fujiwara M, Kanamori H, Fujiwara SI, et al. Adverse events associated with infusion of hematopoietic stem cell products: a prospective and multicenter surveillance study. Transfus Med Rev. 2018 Jun;32(3):186-94. 
46 Sargent B. The use of animal serum in the clinical translation of hMSCs. Blog Post 2016 Feb 18. Available from: https://cellculturedish.com/the-use-of-animal-serum-in-theclinical-translation-of-hmscs/.

47 European Medicines Agency. Guidelines on the use of bovine serum in the manufacture of human biological medicinal products EMA/ CHMP/BWP/457920/2012 rev 1.2013. Available from: https://www.ema.europa.eu/documents/scientific-guideline/guideline-usebovine-serum-manufacture-human-biological-medicinal-products_en.pdf.

48 Food and Drug Agency. Guidance for FDA Reviewers and Sponsors. Content and Review of Chemistry, Manufacturing, and Control (CMC) Information for Human Somatic Cell Therapy Investigational New Drug Applications (INDs). Available from: https://www. fda.gov/biologicsbloodvaccines/guidancecomplianceregulatoryinformation/guidances/cellularandgenetherapy/default.htm.

49 Wang C, Xiao R, Cao YL, Yin HY. Evaluation of human platelet lysate and dimethyl sulfoxide as cryoprotectants for the cryopreservation of human adipose-derived stem cells. Biochem Biophys Res Commun. 2017 Sep; 491(1):198-203.

50 Baust JM, Corwin W, Snyder KK, Van Buskirk R, Baust JG. Cryopreservation: evolution of molecular based strategies. Adv Exp Med Biol. 2016;951:13-29.

51 Baust JG, Snyder KK, Van Buskirk R, Baust JM. Integrating molecular control to improve cryopreservation outcomes. Biopreserv Biobank. 2017 Apr;15(2):134-41.

52 Franks F. The properties of aqueous solutions at sub-zero temperatures. In: Franks F, editor. Water a compressive treatise. Volume 7. New York, London: Plenum Press; 1982. pp. 215338.

53 Morris GJ, Acton E. Controlled ice nucleation in cryopreservation - a review. Cryobiology. 2013 Apr;66(2):85-92.

54 Lauterboeck L, Hofmann N, Mueller T, Glasmacher B. Active control of the nucleation temperature enhances freezing survival of multipotent mesenchymal stromal cells. Cryobiology. 2015 Dec;71(3):384-90.

55 Nishiyama Y, Iwanami A, Kohyama J, Itakura G, Kawabata S, Sugai K, et al. Safe and efficient method for cryopreservation of human induced pluripotent stem cell-derived neural stem and progenitor cells by a programmed freezer with a magnetic field. Neurosci Res. 2016 Jun;107:20-9.
56 Wowk B. Electric and magnetic fields in cryopreservation. Cryobiology. 2012 Jun;64(3): 301-3.

57 Kobayashi A, Golash HN, Kirschvink JL. A first test of the hypothesis of biogenic magnetite-based heterogeneous ice-crystal nucleation in cryopreservation. Cryobiology. 2016 Jun;72(3):216-24

58 Asghar W, El Assal R, Shafiee H, Anchan RM, Demirci U. Preserving human cells for regenerative, reproductive, and transfusion medicine. Biotechnol J. 2014 Jul;9(7):895-903.

59 Massie I, Selden C, Hodgson H, Fuller B. Storage temperatures for cold-chain delivery in cell therapy: a study of alginate-encapsulated liver cell spheroids stored at $-80^{\circ} \mathrm{C}$ or $-170^{\circ} \mathrm{C}$ for up to 1 year. Tissue Eng Part C Methods. 2013 Mar; 19(3):189-95.

60 Brockbank KG, Carpenter JF, Dawson PE. Effects of storage temperature on viable bioprosthetic heart valves. Cryobiology. 1992 Oct;29(5):537-42.

61 Yang J, Diaz N, Adelsberger J, Zhou X, Stevens $\mathrm{R}$, Rupert A, et al. The effects of storage temperature on PBMC gene expression. BMC Immunol. 2016 Mar;17(1):6.

62 Sputtek A, Nowicki B, Rowe A, Kuehnl P. Long-term cryopreservation of human peripheral blood progenitor cells: influence of storage temperature $(-80 \mathrm{C}$ vs $<-170 \mathrm{C})$ on cell recovery, membrane integrity and clonogenicity. Cryobiology. 2004;49:314.

63 Yuan Y, Yang Y, Tian Y, Park J, Dai A, Roberts RM, et al. Efficient long-term cryopreservation of pluripotent stem cells at $-80^{\circ} \mathrm{C}$. Sci Rep. 2016 Oct;6(1):34476.

64 Mazzilli F, Delfino M, Imbrogno N, Elia J, Dondero F. Survival of micro-organisms in cryostorage of human sperm. Cell Tissue Bank. 2006;7(2):75-9.

65 Hawkins AE, Zuckerman MA, Briggs M, Gilson RJ, Goldstone AH, Brink NS, et al. Hepatitis B nucleotide sequence analysis: linking an outbreak of acute hepatitis B to contamination of a cryopreservation tank. J Virol Methods. 1996 Jun;60(1):81-8.

66 McCullough J, Haley R, Clay M, Hubel A, Lindgren B, Moroff G. Long-term storage of peripheral blood stem cells frozen and stored with a conventional liquid nitrogen technique compared with cells frozen and stored in a mechanical freezer. Transfusion. 2010 Apr; 50(4):808-19.

67 Angel S, von Briesen H, Oh YJ, Baller MK, Zimmermann H, Germann A. Towards optimal cryopreservation and storage for achievement of high cell recovery and maintenance of cell viability and T cell functionality. Biopreserv Biobank. 2016 Dec;14(6):539-47.
68 Pogozhykh D, Pogozhykh O, Prokopyuk V, Kuleshova L, Goltsev A, Blasczyk R, et al. Influence of temperature fluctuations during cryopreservation on vital parameters, differentiation potential, and transgene expression of placental multipotent stromal cells. Stem Cell Res Ther. 2017 Mar;8(1):66.

69 Hunt CJ, Song YC, Bateson EA, Pegg DE. Fractures in cryopreserved arteries. Cryobiology. 1994 Oct;31(5):506-15.

70 Baust JM, Campbell LH, Harbell JW. Best practice for cryopreservation, thawing and recovering, and assessing cells. In Vitro Cell Dev Biol Anim. 2017 Dec;53(10):855-71.

71 Simione F, Sharp T. Best practices for storing and shipping cryopreserved cells. In Vitro Cell Dev Biol Anim. 2017 Dec;53(10):888-95.

72 Lecchi L, Giovanelli S, Gagliardi B, Pezzali I, Ratti I, Marconi M. An update on methods for cryopreservation and thawing of hemopoietic stem cells. Transfus Apheresis Sci. 2016 Jun; 54(3):324-36.

73 Röllig C, Babatz J, Wagner I, Maiwald A, Schwarze V, Ehninger G, et al. Thawing of cryopreserved mobilized peripheral bloodcomparison between waterbath and dry warming device. Cytotherapy. 2002;4(6): 551-5.

74 Campbell A, Brieva T, Raviv L, Rowley J, Niss $\mathrm{K}$, Brandwein $\mathrm{H}$, et al. Concise review: process development considerations for cell therapy. Stem Cells Transl Med. 2015 Oct;4(10):115563.

75 Tostoes R, Dodgson JR, Weil B, Gerontas S, Mason C, Veraitch F. A novel filtration system for point of care washing of cellular therapy products. J Tissue Eng Regen Med. 2017 Nov;11(11):3157-67.

76 Barbaric I, Jones M, Buchner K, Baker D, Andrews PW, Moore HD. Pinacidil enhances survival of cryopreserved human embryonic stem cells. Cryobiology. 2011 Dec;63(3):298305.

77 Yang B, Parsha K, Schaar K, Satani N, Xi X, Aronowski J, et al. Cryopreservation of bone marrow mononuclear cells alters their viability and subpopulation composition but not their treatment effects in a rodent stroke model. Stem Cells Int. 2016;2016:5876836.

78 Taylor MJ, Campbell LH. Use of redox indicator assays such as Alamar Blue in the presence of modern storage media containing glutathione: a cautionary tale. Cryobiology. 2000;41: 370-1.
Practical Aspects in the Cryopreservation of Cellular Therapies
Transfus Med Hemother 2019;46:134-149

DOI: $10.1159 / 000497289$ 